\title{
SAMME SAK?
}

\section{LOKALT LEREPLANARBEID ETTER M87 OG LO- KALT ARBEID MED LAERPLANER ETTER LK06.}

M87 framhevet i sin tid betydningen av lokalt læreplanarbeid, og utdanningsmyndighetene utga en veiledning for den lokale læreplanvirksomheten. Ut fra veiledningen fikk lærerne anledning til å benytte sin didaktiske profesjonalitet ved utarbeiding av lokale læreplandokumenter. M87-veiledningen betraktet lærerne som medarbeidere i læreplanutvikling. Til LK06 har Utdanningsdirektoratet også fått utarbeidet veiledninger i lokalt arbeid med læreplaner. Men ut fra LK06-veiledningene er det lett å se for seg skoler og lærere som lydig leverer fra seg elever med det læringsutbyttet som utdanningsmyndighetene forventer.

Artikkelen retter oppmerksomheten mot den veiledningen i lokalt læreplanarbeid som ble publisert i tilknytning til M87 (Grunnskolerådet 1985a), og de to veiledningene i lokalt arbeid med læreplaner som til nå er blitt publisert i tilknytning til LK06 (Utdanningsdirektoratet 2009, 2014).

Allerede mens M87 var under utvikling og hadde blitt utgitt i en midlertidig utgave (M85), ble det publisert et veiledningshefte i lokalt læreplanarbeid (Grunnskolerådet 1985a). Hvordan den lokale virksomheten kunne bli tilrettelagt ut fra LK06, ble det opprinnelig gitt lite veiledning i (jf. Engelsen 2008, 2015). Det ble imidlertid uttrykt $\emptyset$ nsker om bedre veiledning i lokalt arbeid med læreplaner (se f. eks. Engelsen 2008) - noe våre utdanningsmyndigheter fanget opp (jf. St. meld. nr. 31, 2007 - 2008), og Utdanningsdirektoratet publiserte en første veiledning i lokalt arbeid med læreplaner i 2009. Da gjennomgående læreplaner for fag i grunnopplæringen var blitt justert, og de justerte fagplanene var blitt tatt i bruk i skoleåret 2013/14, ble en revidert veiledning publisert på Utdanningsdirektoratets nettside 27.02.14. Teksten i den reviderte veiledningen ble noe endret 12.05.14 (Utdanningsdirektoratet 2014). Ytterligere revideringer er varslet (se Utdanningsdirektoratet 2014). Selv om veiledningsteksten har foreligget i flere versjoner, er hovedbudskapet i veiledningene det samme.

Ulike oppfatninger av veiledninger for lokal læreplanvirksomhet (1) 
Det er påfallende hvor ulikt disse veiledningene og den forventede lokale læreplanvirksomheten blir omtalt.

Hovdenak \& Stray ser veiledningene for den lokale virksomheten ut fra LK06 (Utdanningsdirektoratet 2009, 2014) som uttrykk for en sterk styring fra utdanningsmyndighetenes side (jf. Hovdenak \& Stray 2015, s. 114f). Styring, kontroll og begrenset lærerautonomi er stikkord som også beskriver Mølstads oppfatning av den veiledningen i lokalt arbeid med læreplaner som utdanningsdirektoratet publiserte i 2009. Hun viser til følgende utsagn i veiledningen: «Here [in the document] you receive advice about central choices and tasks in the process of local planning, and how curriculum can be understood and operationalised (Utdanningsdirektoratet 2009, s. 2)" (Mølstad 2015, s. 450). Hun fortsetter: "Additionally, the document mentions that the schools are responsible for choosing methods that can achieve the competence aims of the curriculum, clearly placing this responsibility at the local level ..." (Mølstad 2015, s. 450.)

Hos forfattere som omtalte lokalt læreplanarbeid ut fra M87 og den veiledningen i lokalt læreplanarbeid som ble publisert i 1985 (Grunnskolerådet 1985a), er det et helt annet bilde av den lokale virksomheten som kommer fram (jf. Hegtun, Horsfjord, Møller \& Ålvik 1991; Raaen \& Ålvik 1987). Gjennom veiledningen ble de lokale aktørene invitert inn i et profesjonelt didaktisk arbeid, med mye vekt på didaktisk refleksjon (jf. Hegtun mfl., 1991, s. 207). Gundem (1993, s. 124) viser til Gunleiksrud (1992; se også Bjørnsrud 1993) og konkluderer på denne måten: «Det er altså tydelig at det lokale læreplanarbeidet har bidratt både til bedre og mer effektiv planlegging (og forhåpentlig undervisning) og til videreutvikling og profesjonalisering av lærerne» (Gundem 1993, s. 125).

Hva kan det komme av at veiledningen i lokalt læreplanarbeid etter M87 og veiledningene i lokalt arbeid med læreplaner etter LK06 blir oppfattet å gi så forskjellige lokale handlingsrom? Det vil denne artikkelen søke å gi et svar på. I drøftingen av hvilket handlingsrom veiledningene til de to læreplanene gir de lokale lærerne, tar jeg utgangspunkt i det opprinnelig tyske begrepet lisensiering.

\section{Begrepet lisensiering (1)}

Det tyske lisensieringsbegrepet ble presentert for norske lesere av Gundem (1993) som viste til Hopmann (1991). Opprinnelig var betydningen denne: Lærerne hadde en lisens til å under- 
vise. Det innebar at de hadde metodefrihet når de skulle tilrettelegge for elevenes læring av det innholdet som myndighetene hadde vedtatt for skolens undervisning.

Lisensiering i læreplanarbeidet innebærer et skille mellom læreplanarbeid på statlig plan og læreplanarbeid på undervisningsnivå. Lærerne blir gjort ansvarlige for å iverksette bestemmelser tatt på statlig nivå. De blir gjort ansvarlige for realiseringen av skolens formål, mål og innhold slik dette kommer til uttrykk i læreplanen. Vi kan si at staten gir lærerne en «lisens» som innebærer en moralsk om ikke en juridisk bindende forpliktelse. Dette kan oppfattes som at lærerne står fritt til å velge hvordan de skal utføre sin forpliktelse innenfor sentralt gitte rammer (metodefrihet), men innholdet er bestemt for dem (Goodson 1988, Haft \& Hopmann 1989). (Gundem 1993, s. 35f; jf. Mølstad 2015, s. 446.)

Didaktikken ble tradisjonelt forventet å bidra med et profesjonelt verktøy som lærerne kunne bruke i den metodiske tilretteleggingen av det vedtatte lærestoffet. Didaktiske kategorier (mål, vurdering, innhold, arbeidsmåter, rammefaktorer, elevforutsetninger) skulle kunne danne grunnlag for utvikling av et didaktisk språk og for didaktiske analyse- og planleggingsmodeller. Språket og modellene skulle kunne brukes i profesjonell (didaktisk) planlegging og refleksjon (jf. Mølstad 2015, s. 446).

Norsk tenkning om utdanning var påvirket av dette synet på læreren, og med M87 ble lisensieringen utvidet. Læreren fikk nå ikke bare metodefrihet, men også rett til lokalt å konkretisere innholdet/ lærestoffet. Grunnskolerådets veiledningshefte (1985a) ga et didaktisk basert grunnlag for det lokale læreplanarbeidet. Didaktikken - lærernes profesjonelle verktøy - er derimot fjernet i 2014-veiledningen til LK06. Nå skal lærerne levere (Mølstad 2015: deliver) en undervisning som kan gi elevene et best mulig læringsutbytte i forhold til de oppsatte kompetansemålene og de vedtatte grunnleggende ferdighetene. Mølstad (2015) viser hvordan en fornyet vekt på «accountability» (ansvarsstyring; jf. Langfeldt 2008; Langfeldt, Elstad \& Hopmann 2008; Langfeldt \& Birkeland 2010) i norsk skole under Kunnskapsløftet og med LK06 medfører at lærerne blir gitt en alternativ undervisningslisens:

It is interesting to note how licencing of teachers changes when it is established in a accountability system, instead of a system of trust as it was traditionally placed, which is highly relevant for the Norwegian case. Norway engages in educational testing of the pupils, and the Norwegian curriculum reform is highly centred on educational outcomes through competence aims as a core category in the curriculum (Mølstad \& Karseth, in press). However, this strategy of conceptualizing the curriculum is new in this country. . One may question whether this way of distributing responsibility to the teacher can be labelled as licencing, since it contains a highly restricted autonomy combined with local curriculum work with a focus on delivery of the national curriculum. However, I argue that it is possible to use the term licencing as a way to conceptualize that the Norwegian teachers are granted the responsibility for 
delivery of the national curriculum. As such, the licence of the Norwegian teacher profession involves application of the national curriculum. (Mølstad 2015, s. 456)

LK06 gir lærerne en undervisningslisens som gir dem ansvar for levering ut fra kompetansemålene i den nasjonale og sentralt gitte læreplanen. Ut fra M87 ble lærerne derimot forventet å utvikle læreplaner ut fra en didaktisk basert profesjonalitet.

\section{M87 og LK06: Ulike forståelser av lokal læreplanvirksomhet (1)}

I dette avsnittet spør jeg og tar opp til drøfting: Hva slags forståelse av lokalt læreplanarbeid lå i sin tid til grunn for den veiledningen i lokalt læreplanarbeid som ble publisert parallelt med M87? Hva slags forståelse av lokalt arbeid med læreplaner ligger til grunn for Utdanningsdirektoratets veiledninger (2009 og 2014) i lokalt arbeid med fagplanene i LK06?

Når det gjelder noen sider av den lokale læreplanvirksomheten, gir veiledningene til de to læreplanene uttrykk for relativt sammenfallende oppfatninger.

Vi kan for eksempel skille mellom lokal læreplanvirksomhet som henholdsvis videreutvikling og utprøving av den nasjonale og sentralt gitte læreplanen (jf. Engelsen 2015). I veiledningene fra Utdanningsdirektoratet $(2009,2014)$ ser det ut til å være en fremmed tanke at det lokale arbeidet med læreplanene kan dreie seg om en lokal utprøving av LK06. Heller ikke veiledningen til M87 (Grunnskolerådet 1985a) så lokalt læreplanarbeid som en lokal utprøving av det sentralt gitte plandokumentet - selv om veiledningen viste større åpenhet for lokalt profesjonelt arbeid og refleksjon (se nedenfor). Det var også her lokal videreutvikling av den sentralt gitte læreplanen som sto i fokus.

Både for M87 og for LK06 er det ytterste siktemålet med den lokale planleggingsvirksomheten å gi et godt grunnlag for elevenes læring. Om M87 het det: «Planleggingen er et grunnlag for å kunne skape helhet og sammenheng i elevenes læring i skolen» (Grunnskolerådet 1984, s. 33). I den lokale planutformingen måtte man ta sikte på å organisere lærestoffet i mest mulig meningsfylte helheter for elevene på de ulike klassetrinn innenfor treårsperiodene, minnet planutkastet om (se også Hegtun mfl. s. 72). I veiledningsheftene i lokalt arbeid med læreplaner etter LK06 blir det også framhevet at det endelige siktemålet med den lokale virksomheten er å bidra til at elevene får et godt læringsutbytte. Det angis faser i det lokale planleggingsarbeidet (utarbeidingsfasen, gjennomføringsfasen, vurderingsfasen og oppfølgingsfasen 
(Utdanningsdirektoratet 2014, versjon fra 27.02.15, s. 13ff og versjon fra 12.05.14, s. 11ff), og det blir framhevet at sentralt i alle fasene er elevenes læring av kompetansemålene i LK06.

På tross av visse likheter, er det likevel store forskjeller i veiledningenes beskrivelser av den lokale læreplanvirksomheten.

\section{M87: Didaktisk basert frihet for lærerne (2)}

De sentrale dokumentene i utviklingen fram mot M87 (Grunnskolerådet 1984, 1985a, 1985b, M85) inviterte lærerne til et didaktisk basert profesjonelt lærerarbeid. Utdanningsmyndighetene så for seg profesjonelle lærere som med et didaktisk handlingsrom skulle utvikle lokale læreplandokumenter. Den endelige M87 ble innledet med et brev fra daværende statsråd for utdanning - Kirsti Kolle Grøndahl - til elever, lærere og foreldre. Mottakerne av brevet fikk vite at M87 var tenkt både som en forpliktende ramme for arbeidet i skolen og som en idé- og inspirasjonskilde lokalt. Den skulle gi retning til et aktivt pedagogisk utviklingsarbeid som «kaller på nytenkning, kreativitet og initiativ» (s. 9). Det kollektive ansvaret for det lokale læreplanarbeidet ble understreket, men likevel framhevet man den enkelte lærers frihet. «Hensikten må være å samordne, støtte og veilede, mer enn å styre og kontrollere» (s. 21), het det i Grunnskolerådets veiledningshefte i lokalt læreplanarbeid (Grunnskolerådet 1985a). Derfor burde lokale planer være relativt åpne og fleksible og ikke for detaljerte, fortsatte veiledningsheftet.

Invitasjon til refleksjon (3) I veiledningsheftet til M87(Grunnskolerådet, 1985a) ble de lokale aktørene invitert til et lokalt profesjonelt didaktisk arbeid og til lokale refleksjoner. Man la vekt på utvikling av et felles didaktisk språk - ut fra sentrale didaktiske kategorier: Rammer (ytre og indre), lærestoff, læringsaktiviteter (arbeidsmåter), læringsmål og vurdering (Grunnskolerådet, 1985a, s. 23). Som modell for det lokale arbeidet ble det foreslått en forenklet didaktisk relasjonsmodell (s. 23; om didaktisk relasjonstenkning, se Bjørndal \& Lieberg 1978; Engelsen 1998). De lokale aktørene ble ut fra M87 invitert til å tilrettelegge for en undervisning som skulle være et alternativ til en læreplanstyrt og lærerformidlet kateterundervisning noe som bekreftes av bøker om lokalt læreplanarbeid etter M87 (jf. f. eks. Hegtun mfl. 1991; Raaen \& Ålvik 1987). Forfatterne av disse bøkene søkte å vise at lokalt læreplanarbeid måtte bli forbundet med et alternativt undervisningssyn og med et annet elevsyn enn det tradisjonelle (jf. Raaen \& Ålvik 1987, s. 129). De så for seg et godt handlingsrom for utvikling av lokale læreplaner - utarbeidet med god - didaktisk basert - lærerprofesjonalitet. Denne lærerprofe- 
sjonalitetens lokale arbeid skulle likevel være basert i den sentralt gitte læreplanen, men det så ut til å være lite direkte styring av den lokale aktiviteten. De åpne læreplanrammene og de mange tolkningsmulighetene ble hele tiden framhevet. Det var få direkte bindende retningslinjer. Hegtun m. fl. (1991) inviterte lærerne til didaktisk arbeid og didaktisk refleksjon: «Det planleggingsarbeidet som M87 forutsetter, krever profesjonelle lærere, altså lærere som har relevant bakgrunn for å kunne gjennomføre arbeidet og ta de beslutninger som er nødvendige i en framtidsrettet skole» (s. 22). Det ble understreket at M87 skulle være et arbeidsredskap for lærerne. Felles begreper og et felles læreplanspråk var nødvendig dersom lærerne skulle gå sammen og begrunne praksis, sa forfatterne. I samsvar med Grunnskolerådets veiledning (Grunnskolerådet 1985a) foreslo forfatterne den didaktiske relasjonsmodell både som tankemodell og som redskap for dette arbeidet. Forfatterne kom med en invitasjon til profesjonelt didaktisk arbeid når de sa følgende:

. . . dere må legge opp til en vekselvirkning mellom flere typer autoriteter, både i M87, læreboka og deres egen fagforståelse. Alle disse autoritetene må få bryne seg mot hverandre. Det for eksempel viktig å få et bevisst forhold til hva læreboka egentlig formidler, og om den er forenlig med egen fagforståelse og M87. En bør ha så mye profesjonell selvtillit at en ikke uten videre underordner egen fagforståelse under de andre typene autoriteter. Og en bør ha så mye ydmykhet at en holder muligheten åpen for å endre sin egen fagforståelse. (Hegtun mfl. 1991, s. 179.)

I Grunnskolerådets veiledningshefte (Grunnskolerådet 1985a) ble det foreslått «oppgaver til drøfting» (s. 61f) i tilknytning til det lokale læreplanarbeidet: «Oppgavene er ment som ideer og forslag til drøftingstemaer. Hensikten er å vise at drøftingene og vurderingene må rettes inn mot egen situasjon og eget arbeid» (s. 61). Dette er noen av de foreslåtte drøftingstemaene:

- Hva kan vi oppnå med lokalt læreplanarbeid ved vår skole?

- Hvordan vurderer vi dette arbeidet i forhold til

- vårt personale,

- våre elever og foreldre

- våre ressurser: budsjett, timetall og utstyr

- vårt lokalmiljø?

- Hvilke muligheter ser vi?

- Hvilke hindringer? (Grunnskolerådet 1985a, s. 61.)

Ingen av de foreslåtte drøftingstemaene dreiet seg direkte om måloppnåelse og forventet læringsutbytte selv om noen drøftingstemaer nok indirekte dreiet seg om formålsproblematikk: 
- Vurder forholdet mellom prosess og produkt i læreplanarbeidet. Hvordan kan vi best legge til rette for en positiv utvikling ved vår skole?

- Hvor omfattende og detaljerte felles læreplaner ønsker vi?

- I hvilken grad bør slike planer være bindende for arbeidet i klassene?

- Hva kan vi oppnå ved vår skole med en felles arbeidsplan? Hvordan kan planen lette og forbedre arbeidet vårt?

- Hva bør arbeidsplanen inneholde?

- Hvordan skal vi legge opp arbeidet med denne planen hos oss, forberedelse, forslag, behandling? (Grunnskolerådet, 1985a, s. 61.)

\section{LK06: Tilsynelatende lærerfrihet (2)}

På Utdanningsdirektoratets hjemmeside blir det lagt vekt på lokale utforminger av LK06. Man får inntrykk av at myndighetene vil la «de tusen blomster blomstre». Men er dette en riktig forståelse? 2014-veiledningen (begge versjoner) framhever riktignokat det blir gitt få føringer for den lokale læreplanvirksomheten, og at det lokale handlingsrommet er stort: «LK06 gir et stort lokalt handlingsrom slik at opplæringen skal kunne tilpasses den enkelte elev, elevgruppe og lokale behov og prioriteringer» (Utdanningsdirektoratet 2014, versjon 12.05.15, s. 6). Samtidig blir det imidlertid understreket at hele LK06 må bli ivaretatt gjennom den lokale læreplanvirksomheten. «Ingen kompetansemål kan velges bort, med mindre en elev har vedtak om rett til spesialundervisning» (Utdanningsdirektoratet 2014, versjon 12.05.14, s. 4). Veiledningen framhever at «Elevene skal i praksis oppleve at opplæringen er i samsvar med nasjonale målsettinger, og at de lokale føringene som er gjort er innenfor dette handlingsrommet» (s. 15). De lokale lærerne blir altså forventet å levere fra seg elever med et best mulig læringsutbytte i forhold til alle kompetansemål i LK06.

I den opprinnelige wordversjonen av veiledningen fra 2009 kunne det se ut som om det lokale handlingsrommet var stort. Der var det, til inspirasjon for den lokale læreplanvirksomheten, lagt inn konkrete eksempler på hvordan man hadde bedrevet lokalt arbeid med læreplaner i navngitte kommuner og på navngitte skoler. De konkrete eksemplene var imidlertid fjernet da veiledningen fra 2009 ble publisert i en PDF-versjon. I 2014-versjonen av veiledningen (versjonen fra 12.05.14) ser det ut til at man i større grad ønsker å styre den lokale læreplanvirksomheten. Der blir det beskrevet hvordan ikke navngitte skoleeiere (vedlegg 3) og ikke navn- 
gitte skoleledere (vedlegg 4) kan utføre det lokale arbeidet (se også malen for hvordan den lokale virksomheten kan bedrives i vedlegg 5). I disse vedleggene ser det nærmest ut som om man har laget huskeregler som de lokale aktørene kan benytte i læreplanvirksomheten.

Vurdering av hvorvidt elevene når det forventede læringsutbytte blir gitt relativt stor plass i 2014-veiledningen (versjon 12.05.14) «Alle elever har rett til vurdering», heter det (s. 5), og hva denne vurderingen omfatter, blir utdypet lenger ut i veiledningsdokumentet (s. 22ff). Retningslinjer for vurdering styrer da indirekte den lokale læreplanvirksomheten. Tilsynelatende har de lokale aktørene stort handlingsrom og stor frihet når de skal velge innhold og arbeidsmåter til sin undervisning, men handlingsrommet og friheten blir strammet inn ved hjelp av opplegg for vurdering. Forskning har for lengst vist at det som er viktig i sentrale vurderinger(som f. eks. nasjonale prøver), blir sentralt også i undervisningen lokalt. Det tilsynelatende store handlingsrommet blir begrenset av en rekke retningslinjer for vurderingen.

Med andre ord: Det store handlingsrommet som utdanningsreformen Kunnskapsløftet tilsynelatende innrømmer de lokale lærerne, er nettopp det - tilsynelatende. Veiledningene i lokalt arbeid med læreplaner $(2009,2014)$ dokumenterer at den sentrale styringen er ganske sterk (jf. Mølstad 2015). I veiledningene finner vi liten vekt på de lokale lærernes profesjonelle kompetanse. De didaktiske kategoriene var for så vidt med i 2009-utgaven av veiledningen, og ulike planleggingsmodeller ble nevnt uten at det ble forklart hvordan de kunne benyttes (jf. Engelsen 2015). I 2014-utgaven er didaktikken nesten vekk. Det gjelder de didaktiske kategoriene, det felles didaktiske språket og didaktiske planleggingsmodeller. Veiledningen fra 2014 klargjør i stedet sentrale læreplanelementer i LK06 som for eksempel kompetansemål og grunnleggende ferdigheter (jf. Utdanningsdirektoratet 2014, versjon fra 12.05.14, s. 17ff).

Invitasjon til refleksjon? (3)Veiledningene foreslår refleksjonsspørsmål i tilknytning til den lokale læreplanvirksomheten (jf. Utdanningsdirektoratet, 2009, PDF-versjonen, s. 13; Utdanningsdirektoratet, 2014, versjon 27.02.14, s. 26ff og versjon 12.05.14, s. 25). De lokale aktørene blir for eksempel invitert til å reflektere over temaet skolens brede mandat, men de foreslåtte refleksjonsspørsmålene dreier seg kun om hvordan operasjonalisere læreplanens del 1 Generell del - og læreplanens del 2 - Prinsipper for opplæringen

- Hva i Generell del av læreplanen og Prinsippene for opplæringen bør prioriteres i lokale læreplaner for fag?

- Hvordan kan skolen som et sosialt og inkluderende fellesskap bidra til å styrke elevenes læring? 
- Hvordan kan kompetansen i fag bidra til å realisere skolens brede mandat, slik det kommer til uttrykk i Generell del og i Prinsipper for opplæringen? (Utdanningsdirektoratet, 2014, versjon fra 27.02.14, s. 26 og versjon fra 12.05 .14$, s.25)

I Vedlegg 2 til 2014-veiledningen (versjon fra 12.05.14) blir det foreslått refleksjonsspørsmål til skolens arbeid med LK06 som helhet: «Matrisen inneholder forslag til refleksjonsspørsmål som kan brukes i prosessen med å sikre at lokale læreplaner ivaretar LK06 som helhet i utarbeiding, gjennomføring, evaluering og oppfølging av lokalt arbeid med læreplaner. Refleksjonsspørsmålene er først og fremst rettet mot skolens arbeid, men kan være nyttige også for skoleeierne». Nedenfor blir det gitt noen eksempler på de foreslåtte refleksjonsspørsmålene

\section{Formål med faget}

- Synliggjør lokal læreplan intensjonen med faget som helhet?

- Hvilke muligheter gir formål med faget for å arbeide med utvikling av sosial kompetanse

\section{Hovedområder i faget}

- Er alle hovedområdene dekket i lokal læreplan?

- Sees hovedområder i sammenheng?

- Samarbeider lærere på tvers av fag for å se lokale læringsmål for ulike fag i sammenheng?

\section{Grunnleggende ferdigheter}

- Synliggjør lokal læreplan hva arbeid med grunnleggende ferdigheter i faget innebærer?

- Synliggjør lokallæreplan progresjon i grunnleggende ferdigheter?

Refleksjonsspørsmålene er relativt grunne. De ser ut til å ta opplæringssynet og fagsynet i LK06 for gitt. De inkluderer i liten, om noen, grad drøftingsspørsmål rundt læreplanens syn på opplæring og fag. Lærerne blir ikke invitert til å delta i mer grunnleggende refleksjoner om siktemålet med utdanning og undervisning, samt hvorvidt LK06 er et godt redskap for å nå skolens totale målsetting. «Refleksjonsspørsmålene» ser nærmest ut som en huskeliste som lærerne kan krysse av på for å sjekke om de legger til rette en opplæring som vil gi elevene et godt læringsutbytte i forhold til den nasjonale læreplanens lister over kompetansemål..

Profesjonell lokale læreplanvirksomhet - et didaktisk grunnlag? (2) 
Lærersynet ser ut til å ha skiftet fra M87 til LK06.

Ut fra en tradisjonell tysk-kontinental tenkning blir didaktikken sett på som de profesjonelle lærernes faglige grunnlag (jf. Gundem 1993; Hopmann 1991; se også Mølstad 2015). Den gir dem et felles språk og planleggingsmodeller - begge bygger på didaktiske kategorier (se ovenfor). Og didaktikken gir grunnlag for lærernes profesjonelle handlingsrom i tilrettelegging av undervisning. M87 og veiledningen i lokalt læreplanarbeid ut fra denne læreplanen bygde på et tilsvarende lærersyn. Ut fra M87 ble lærerne forventet å være utviklere av lokale planer, på grunnlag av profesjonelt didaktisk arbeid og refleksjon (se ovenfor).

LK06 og veiledningene i lokalt virksomhet ut fra denne læreplan ser ikke ut til å bygge på dette lærersynet. Med denne læreplanen har vi trolig beveget oss i retning av en mer anglosaksisk læreplantenkning. Lærerne blir ut fra LK06 forventet å vise kunnskaper, ferdigheter og refleksjoner innenfor læreplanen. Med andre ord: De skal ha de kunnskapene, ferdighetene og refleksjonene som er et nødvendig grunnlag for å føre elevene til det fastsatte læringsutbyttet (jf. Skar, 2012).

Den profesjonelle lærer blir riktignok hevdet å ligge til grunn for LK06 (Stortingsmelding nr. 30, 2003 - 2004), men veiledningene ser i større grad ut til å gi uttrykk for et funksjonærsyn på lærerne -de blir forventet å levere det som myndighetene gjennom læreplanen har bestemt. Et viktig spørsmål blir da: Hva er en profesjonell lærer - ut fra LK06 med grunnlagsdokumenter? Ut fra 2014-veiledningen ser de lokale aktørene ikke ut til å bli forventet å jobbe didaktisk med LK06. Mens man i tilknytning til M87 framhevet en vid profesjonell lærerrolle, er det tilsynelatende en begrenset profesjonalitet det er snakk om i tilknytning til LK06: Lærerne blir forventet å tilrettelegge for den læringen som læreplanen krever, men lærerne blir ikke forventet å ha synspunkter på læreplanproblematikk utover det som skjer internt i klasserommet og i andre læringssituasjoner. Dette i motsetning til M87 der forfattere som skrev om lokalt læreplanarbeid, inviterte lærerne til å være reelle læreplanutviklere - ikke bare tilretteleggere av læringssituasjoner.

\section{Lokal læreplanvirksomhet i fremtidens skole (2)}

I Ludvigsenutvalgets innstilling om fremtidens skole (NOU 2015: 8), blir det gitt følgende forståelse av det lokale arbeidet med læreplaner: 
For lærerne handler det lokale arbeidet med læreplaner om å tilegne seg nye læreplaner, arbeide med disse og se dette arbeidet og undervisning og vurdering under ett, som deler av planlegging av elevenes læringsarbeid. Det profesjonelle fellesskapet på skolen får på denne måten nye utfordringer, men også mange impulser for planlegging, gjennomføring og refleksjon omkring undervisning. (s. 92.)

Ut fra dette sitatet ser lokalt arbeid med læreplaner ut til å dreie seg om å tilegne seg den «rette forståelsen»av læreplandokumentet («tilegne seg nye læreplaner») og avgjort ikke om å prøve ut nye læreplaner. Oppgaven er å operasjonalisere og konkretisere dem eller med andre ord om å videreutvikle dem innenfor rammen av sentralt gitte bestemmelser.

Ludvigsenutvalget kan med andre ord plasseres i forlengelsen av LK06. Innstillingen rommer ingen nye spennende tanker om undervisning, men representerer når det gjelder, undervisningssyn bare en forlengelse av trender i LK06. Lærersynet kan tolkes i retning av en lærer som utfører de forventede undervisningsoppgavene og oppnår forventet læringsutbytte hos elevene. På tross av profesjonelle lærere framheves som viktig tema i grunnlagsdokumentene rundt LK06, ser vi fortsatt en tendens bort fra den didaktisk sett profesjonelle lærer M87 framhevet - læreren som har et handlingsrom og utnytter det når han utviklet lokale læreplaner?

\section{Konklusjon: Avhengig av veiledningens beskaffenhet (1)}

Jeg innledet denne artikkelen med å vise at forfattere har oppfattet lokal læreplanvirksomhet forskjellig ut fra de veiledningene som er utarbeidet for slik virksomhet med utgangspunkt $\mathrm{i}$ henholdsvis M87 og LK06. Hovdenak \& Stray (2015) synes å mene at enhver veiledning i lokalt læreplanarbeid vil være preget av utdanningsmyndighetenes styringslyst (se ovenfor). At dette gjelder veiledningene i lokalt arbeid med læreplaner etter LK06 (Utdanningsdirektoratet 2009, 2014), er jeg for så vidt enig i, men mener at graden av styring vil være avhengig av hvordan veiledningene er utformet. Å gi gode råd om hvordan lærerne kan angripe det lokale arbeidet, er ikke ensbetydende med å ta fra dem et profesjonelt handlingsrom. Det er ikke eksistensen av en veiledning som er det avgjørende, men det handlingsrommet veiledningen gir de lokale aktørene. Der er veiledningsheftet til M87 og veiledningene til LK06 forskjellige. Veiledningene gir uttrykk for ulike lærersyn: Veiledningen til M87 ga lærerne et godt handlingsrom. Dette handlingsrommet ble de forventet å fylle ved hjelp av et didaktisk planleggings- og refleksjonsverktøy. 2014-veiledningen til LK06 søker å klargjøre sentrale elementer og begreper i den sentralt gitte læreplanen - uten å gå veien om didaktikken. M87 og veiledningsheftet i lokalt læreplanarbeid søkte å stimulere de lokale lærerne til å utvikle lokale 
læreplaner - riktignok innenfor rammen av den sentralt gitte Mønsterplanen. Denne forståelsen av M87 støttes av Hegtun m. fl. 1991 og Raaen \& Ålvik 1987 (se ovenfor). Veiledningsheftene i lokalt arbeid med læreplaner etter LK06 ser ut til å betrakte de lokale lærerne som utførere og leverere - de blir forventet å operasjonalisere og konkretisere den sentralt gitte og nasjonale læreplanen mest mulig i samsvar med listene over kompetansemål i det sentralt gitte læreplanverket.

\section{LITTERATUR}

Bjørndal, Bjarne \& Sigmund Lieberg (1978). Nye veier i didaktikken. Oslo. Aschehoug Bjørnsrud, Halvor (1993). M87 - Mange erfaringer rikere. Prosjekt: Laereplananalyse og erfaringsdokumentasjon M87. Kirke-, utdannings- og forskningsdepartementet, KUF.

Engelsen, Britt U. (1998). Didaktisk relasjonstenkning - et 20-årsjubileum. Norsk Pedagogisk Tidsskrift, 81, 4/5, s. 240 - 251

Engelsen, Britt U. (2008). Kunnskapslфftet. Sentrale styringsstrategier og lokale strategidokumenter. Oslo: Universitetet i Oslo. Pedagogisk forskningsinstitutt. Forskningsgruppen Læreplanstudier. Forskningsprosjektet ARK. Rapport nr. 1. Med støtte fra Utdanningsdirektoratet.

Engelsen, Britt U. (2015). Skolefag i laereplanreformer 1939 - 2013. Oslo: Gylendal Akademisk.

Goodson, Ivor F. (198). The Making of Curriculum. Collected Essays. London: Falmer Press.

Grunnskolerådet (1984). Hфringsutkast til Mфnsterplan for grunnskolen. Revidert utgave.

Generell del. Med foreløpig innstilling om arbeidet og notat om skolen og samfunnsutviklingen. Oslo: Universitetsforlaget.

Grunnskolerådet (1985a). Lokalt laereplanarbeid. Veiledningshefte til revidert Mфnsterplan for grunnskolen, midlertidig utgave. Oslo: Universitetsforlaget.

Grunnskolerådet (1985b). Høringsutkast til Mфnsterplan forgrunnskoen. Revidert utgave. Fagplandel. Med forelфpig innstilling, del 2. Oslo: Universitetsforlaget

Gundem, Bjørg B. (1993). Mot en ny skolevirkelighet? Lareplanen i et sentralisering- og desentraliseringsperspektiv. Oslo: Ad Notam Gyldendal. 
Gunleiksrud, Kristin (1992). Bakgrunnen for læreplanrevisjonen. Grunnskolenytt, 2, 92, s. 30 $-36$.

Haft, Henning \& Stefan Hoppmann (1989). State-run curriculum development in the Federal Republic of Germany. Journal of Curriculum Studies, 2 (2), 185 - 190.

Hegtun, Arnhild, Vidar Horsfjord, Jorunn Møller \& Trond Ålvik (1991). Skolens egen lareplan. Fra praksis til plan - fra plan til praksis. Oslo: Cappelen.

Hopmann, Stefan (1991). The Multiple Realities of Curriculum Policy Making. Paper for Presentation American Educational Research Association, AERA, Annual Meeting, April3-7, Chicago, International Relations Committee Symposium, International Perspectives on Curriculum History: The Social System of Curriculum Policy and Reform.

Hovdenak, Sylvi S. \& Janicke H. Stray (2015). Hva skjer med skolen? En kunnskapssosiologisk analyse av norsk utdanningspolitikk fra 1990-tallet og frem til i dag. Bergen: Fagbokforlaget.

LK06. Lareplanverket for Kunnskapslфftet. Oslo: Utdanningsdirektoratet (Læreplaner for gjennomgående fag i grunnopplæringen ble gjort gjeldende fra skoleåret 2013/2014; se Udir.no).

Langfeldt, Gjert (2008). Ansvar og kvalitet: Strategier for styring i skolen. Oslo. Cappelen Damm.

Langfeldt, Gjert, Eyvind Elstad \& Stefan Hopmann(2008). Ansvarlighet i skolen. Politiske spфrsmål og pedagogiske svar. Oslo. Cappelen Damm.

Langfeldt, Gjert \& Nils R. Birkeland (2010). PISA i lys av styringsteori. I Eyvind Elstad \& Kirsten Sivesind (red.). PISA - sannheten om skolen? Oslo. Universitetsforlaget. 83 99.

M85. Mфnsterplan for grunnskolen. Revidert og midlertidig utgave 1985. Oslo: Aschehoug.

M87. Mфnsterplan for grunnskolen av 1987. Oslo: Aschehoug

Mølstad, Christina E. (2015). State-based curriculum-making: approaches to local curriculum work in Norway and Finland. Journal of Curriculum Studies, 47 (4), 441 - 461. http://dx.doi.org/10.1080/00220272.2015.1039067 
Mølstad, Christina E. \& Berit Karseth (in press). National curricula in Norway and Finland. The role of learning outcomes.(upublisert).

NOU 2015: 8. Fremtidens skole. Fornyelse av fag og kompetanser

Raaen, Finn D. \& Trond Ålvik (1987), red. Håndbok i lokalt laereplanarbeid. Oslo: Gyldendal

Skar, Stine. G. (2012). Larerkompetanse og laererprofesjonalitet. Analyse av St. m. 11 (2008 - 200)9. Lareren, rollen og utdanningen. Masteroppgave i didaktikk og organisasjonslæring. Oslo: Universitetet i Oslo. Pedagogisk forskningsinstitutt.

St. meld. Nr. 30 -82003 - 2004). Kultur for laring. Kunnskapsdepartementet

St. meld. Nr. 31 (2007 - 2008). Kvalitet i skolen. Oslo: Kunnskapsdepartementet.

Utdanningsdirektoratet (2009). Veiledning i lokalt arbeid med lareplaner. Udir.no

Utdanningsdirektoratet (2014). Veiledning i lokalt arbeid med laereplaner. Udir.no http://www.udir.no/Lareplaner/Veiledninger-til-lareplaner/Veiledning-i-lokalt-arbeidmed-lareplaner/ 